\title{
Performance Appraisal and Promotion Practices of Public Commercial Banks in Bangladesh- A Case Study on ACR Method
}

\author{
Nishath Anjum ${ }^{1}$, Md. Mashfiqur Rahman² \\ ${ }^{1}$ Metropolitan University, Sylhet, Bangladesh \\ 2 Agrani Bank Limited, Sylhet, Bangladesh \\ * Corresponding author: nishath@metrouni.edu.bd
}

\begin{abstract}
Article History
Received 2021-03-05

Revised 2021-03-25

Accepted 2021-04-08

Published 2021-04-20
\end{abstract}

\section{Keywords \\ Performance Appraisal \\ Promotion \\ Public Commercial Banks \\ ACR \\ Bangladesh}

\section{How to cite?}

Anjum, N., \& Rabman, M. M. (2021).

Performance Appraisal and Promotion

Practices of Public Commercial Banks in

Bangladesh- A Case Study on ACR

Method. SEISENSE Journal of

Management, 4(3), 1-16. doi:

$10.33215 /$ sjom. $24 i 3.602$
Purpose- Performance appraisal is crucial for enhancing the productivity of employees working in any sector. This paper investigates the prevailing performance appraisal system and promotion policy of selected public commercial banks (Sonali Bank Ltd, Rupali Bank Ltd, and Agrani Bank Ltd) in Bangladesh.

Design/Methodology- The study is a descriptive case of three banks. The researchers interviewed six experienced banking professionals who provided rich data about their respective banks' performance appraisal and feedback systems. The findings of the study are based on the thematic analysis of the respondents' statements. However, the study also utilized secondary sources for other relevant information.

Findings- The study found that all the banks have an established system for evaluating employee performances through ACR with structured criteria for the promotion. The standard criteria include ACR, academic degree, banking diploma, length of service, etc. However, the grading scale for promoting to different positions is differing among the banks. The study also addressed some limitations of the ACR method as rating only by the manager, biasness on ratings, no appraisal feedback to employees etc.

Practical Implications- The study seeks to drive the attention of policymakers to utilize their existing performance appraisal system better and design a more effective one with a well-established promotion policy to encourage the employees to give their best effort at the workplace. 


\section{Introduction}

Performance appraisal is one of the most common management practices utilized in all organizations worldwide (Armstrong, 2009). It is a systematic attempt to distinguish the more efficient workers from the less efficient ones and discriminate among individuals' strengths and weaknesses across many job elements. In short, performance appraisal is a measurement of how well someone performs job-relevant tasks (Tziner \& Kopelman, 2002). This particular process helps the employees know their problems and potentialities, which allows them to achieve the desired improvements in work performances (Gardner, 2008). Moreover, the need for training and development activities is identified by assessing employees' performance and various rewards or incentives are given in recognition of their achievements (Chen \& Eldridge, 2010). Effective performance appraisal outcomes include improving performance, increasing motivation, reducing turnover and establishing linkage between performance and rewards (Dobbins, Cardy, \& Platz-Vieno, 1990).

The banking system plays a significant role in the economic life of any nation. After the emergence, the banking system of Bangladesh has expanded a lot in the last five decades (Talukder, Hossain, \& Hossain, 2014). Whereas the nationalized commercial banks cover the major portion of government banking, the private banking sector has also emerged gradually and taken the upper hand in retail banking (Chowdhury, 2002). Regardless of private or public, all the banks are working hard to make a very performing and competitive human resource management system (M. Rahman, Abdul, Ali, Uddin, \& Rahman, 2017; Mohammad Mizanur Rahman et al., 2018). That is why performance appraisal has become one of the most vital tools of designing an effective HRM (Khan, 2013). To achieve the banks' effectiveness, good performance appraisal plays a significant role (Khanna \& Sharma, 2014). It is imperative to evaluate the bank employees' performance periodically to determine their efficiency level and make them understand how far they are from the expected standards to improve their performances (Mohammad M Rahman, Uddin, \& Rahaman, 2019).

Almost all the banks (both public and private) in Bangladesh carry out a performance appraisal system to measure their employee performances and provide feedback (rewards or punishment) accordingly. Among the various performance appraisal methods, the banking sector of Bangladesh mainly uses the Annual Confidential Report (ACR) method. It is a traditional and one of Bangladesh's most popular appraisal techniques (Absar, Hossain, \& Alam, 2007). Most of the banks, especially the public banks, use this method because of the banking systems' inner setup and confidentiality, making it difficult for them to choose any other method for evaluating employee credentials (Khanna \& Sharma, 2014). However, intense competition leads private sector banks to become concerned about productivity and profitability. They are trying to make their appraisal system more effective by designing well-established criteria with a combination of ACR and other appraisal tools. But the public banks are still using the traditional ACR for appraising employee performances with little or no modifications in the evaluation criteria.

In most cases, structured criteria for promotion are given more priority than the employees' actual performance in public banks of Bangladesh (Jahan, 2016). Due to the inappropriateness of the evaluation system, the employees of these banks are demotivating to give their best efforts even the qualified employees are losing interest too. These issues significantly and often negatively influence the overall performances of the public commercial banks (Khan, 2013), thus raising the need for investigation in this topic area.

The augmentation of this study is to acquire a practical orientation of the performance appraisal and promotion system of the public commercial banks in Bangladesh. The research examines the present practicing criteria of performance evaluation and promotion of the three renowned state-owned banks (Sonali Bank Ltd, Rupali Bank Ltd, Agrani Bank Ltd) of Bangladesh. Knowing how the banks are utilizing their appraisal tools might help the policymakers improve the policies related to the appraisal systems of financial sectors, enhancing the organization's overall performance. 


\section{Research Objectives}

- To provide an insight into the performance appraisal and promotion practices of public commercial banks in Bangladesh.

- To give an in-depth understanding about the practice of ACR method to assess employee performances in public banks of Bangladesh.

- To identify the similarity and differences among the practicing promotion policy of the studied banks.

\section{Performance Appraisal}

Performance is an outcome or result of an individuals' actions. Performance appraisal (also performance assessment, evaluation, measurement) is the continual review of an individuals' job-related task accomplishments within the organization (Chen \& Eldridge, 2010). It is a systematic evaluation of employee performances by identifying their strengths and weaknesses and providing feedback on which performance adjustments can be made (Bhatia \& Jain, 2012). This feedback gives managers and employees opportunities to discuss how employees are progressing and what sort of training or learning opportunities should be given to building on their job skills (Grote, 2002; Kondrasuk, 2011; Wangithi \& Muceke, 2012). The human resource objective for using performance appraisal is to determine who should be promoted, demoted, transferred, or terminated (Obisi, 2011; Rahim, 2012). The managers or supervisors usually drive this continuous assessment using the organizations' appraisal framework (Manjunath, 2015). Good performance appraisal promotes a shared understanding of individual needs, work objectives and acceptable performance standards (Gichuhi, Abaja, \& Ochieng, 2013). Thus, the organizational goals are more effectively achieved and the employees get benefitted in terms of recognition, feedback, career guidance and development (Seniwoliba, 2014).

Performance can be measured by both subjective and objective methods (Latham, Borgogni, \& Petitta, 2008; Lawler III \& McDermott, 2003). The common traditional performance appraisal method includes essay method, paired comparison, ranking method, forced distribution, graphic rating scale, checklist, confidential report, critical incident method etc. (Aggarwal \& Thakur, 2013). However, to improve the limitations like biases and subjectivity of the traditional methods (Shaout \& Yousif, 2014), many modern techniques have been developed such as the balanced scorecard, behaviorally anchored rating scale (BARS), management by objectives (MBO), psychological appraisal, assessment center etc. (Dessler, 2006; Gomez-Mejia, Balkin, Cardy, $\&$ Carson, 2007). The performance raters in most organizations are the immediate supervisor, managers, peers, subordinates, rating committee, self-rating, customer, or even a combination of many (Vijay \& Jayachitra, 2010).

\section{Rationale of the Study}

In the banking sector of Bangladesh, almost all the performance appraisal is dedicated to evaluate the employees for their next promotion. In Bangladesh, ACR is the most common tool for assessing employee performances in the banking sector (Khan, 2013). An annual confidential report (ACR) is a report on the subordinates' performance by his superior concerning attendance, teamwork, discipline, integrity, quality, and quantity of output, failures, achievements, personal traits etc. (Khanna \& Sharma, 2014). There are many other indicators as well (Rahim \& Islam, 2019). In a real sense, ACR is nothing but the impression of the superior about his subordinates. There are many shortcomings in performance appraisal by ACR such as the biasness of evaluator, inaccurate grading, miscalculation of marks, adverse ratings etc. (Hossain, Abdullah, \& Farhana, 2012).

In the banking sector of Bangladesh, the manager is considered as the only evaluator of his subordinates and has a significant role in deciding the reward or punishment for the appraise (Talukdar \& Saha, 2007). In many banks, the superior could get influenced by various external powers for using their evaluation in favor of specific employees. Moreover, various other factors could influence the raters' judgment and they may put high or low marks depending on their liking or disliking (Jahan, 2016). So, the managers have the supreme power to affect 
the employees' careers through ACR (Rahim \& Islam, 2019). Additionally, the performance appraisal through ACR lacks proper feedback to the employees because ACR is highly secretive and could only be viewed by the authorized personnel. Thus, the employees are not getting any chance to improve their performances before receiving the punishments (Latif, 2015). In most cases, the employees remain unaware of the appraisal system and dissatisfied with the methods and behavior of their supervisor in measuring performances (Talukder et al., 2014). Many authors suggested not only rely on ACR and to use a combination of various modern methods for effective performance appraisal. It is also essential to make the employees familiar with the appraisal tools that could improve their understanding of performance objectives and accept those objectives (Absar et al., 2007).

\section{Methodology}

\section{Data Sources and Sample}

The study is based on three public commercial banks' performance appraisal and promotion practices (Sonali Bank Ltd., Rupali Bank Ltd., and Agrani Bank Ltd.) in Bangladesh. Among the six public commercial banks currently operating in Bangladesh, the three banks selected in this study are based on their year in operation, authorized and paid-up capital, functioning, and reputation for services. However, the information about performance appraisal and evaluation criteria for promotion is considered confidential in any financial institution. So, the access to get these data as well as the willingness of the respondents' to provide such information also acted as fundamental forces behind choosing the three banks. Additionally, all the selected banks are using the Annual Confidential Report (ACR) method to conduct the performance appraisal with established evaluation criteria for the promotion.

The study used the interview method to collect the primary data. Six banking professionals with eight or more years of experience from the three selected banks have been interviewed through convenient sampling. The participants' information is given below-

\begin{tabular}{ccccc}
\hline Participant & Designation & $\begin{array}{c}\text { Experience } \\
\text { (Years) }\end{array}$ & Bank & $\begin{array}{c}\text { Interview Duration } \\
\text { (Minutes) }\end{array}$ \\
\hline A & Assistant General Manager & 12 & Sonali Bank Ltd & 15.33 \\
B & Senior Principal Officer & 9 & Sonali Bank Ltd & 17.13 \\
C & Senior Officer & 8 & Rupali Bank Ltd & 26.44 \\
D & Deputy General Manager & 11 & Rupali Bank Ltd & 11.07 \\
E & Principal Officer & 8 & Agrani Bank Ltd & 21.32 \\
F & General Manager & 9 & Agrani Bank Ltd & 19.01 \\
\hline
\end{tabular}

Source: Authors survey

The secondary data collected from various sources as published articles, government records, books, authentic blogs, websites and HR policy manual of the three selected banks have been used for relevant information to support the primary data and to construct the literature part.

\section{Method}

The study is qualitative. The respondents were asked about the performance appraisal and promotion system currently being used in their respective banks. The conversation has been recorded for the convenience of the interpretation. Due to the small size of the sample, the study applied manual analysis to draw the findings. The research was thematic based on the statement of the respondents. Moreover, the selected banks' HR policy manuals have also been utilized to explore the performance evaluation criteria and marks distribution for promotion to different positions. 


\section{Findings and Analysis}

\section{Sonali Bank Ltd.}

Along with the traditional ACR to measure employees' annual performance, Sonali bank also evaluates employees' monthly performance by assessing the achievement of set targets on deposit collection, loan and advance, profit, export and import, non-interest income, and classified loan recovery, etc. (Participant A). According to Participant A,

\section{"Measuring the target achievements and analyzing the ACR are the tools used for performance evaluation in Sonali}

\section{Bank Ltd."}

According to Participant B, the ACR of Sonali bank ltd is divided into two parts. The first part of the ACR measures the qualitative facts such as the employees' mental strength, personality, timeliness, work ethics, dress codes, responsibility, communication skills, leadership, creativity, ability to work under pressure, dedication, motivation, etc. The second part of the ACR is comprised of the quantitative fact where the employee is evaluated on indicators depending on their working area. There is a different performance standard for the branch office employees and the employees of the controlling office as the type of duties vary a lot for these two groups. Participant B quoted that,

"Usually the employees working in the branches have to deal with the general public and are subject to a lot of mental pressure than the employees of controlling office. This is why the employees in different offices are measured with different performance standards".

Participant B further added that,

"As the governing bank of all other commercial banks, Sonali bank has more branches with many employees. And it is not an easy task to maintain a good standard among every employee. Thus, the performance of employees in Sonali bank is usually considered satisfactory unless the employee commits a grave crime".

Table-1: General Criteria of Performance Evaluation and Marks Distribution for Promotion in Sonali Bank Ltd.

$\begin{array}{lll}\text { S.N. Basis } & \text { Total Points } & \text { Segregation of Points }\end{array}$

1 ACR $50 \quad$ The average point of the last three years ACR

2 Educational qualification

15 Educational qualification:

a. Masters/4 years Honours- 15 Points

b. 3 years Honours-14 points

c. 2 years Honours- 13 points

d. HSC- 12 points

e. SSC- 11 points

3 Professional qualification(Banking Diploma/CA/ICMA)

4 Length of Service (In present grade)
5

15 a. CA/CMA/CPA/ Banking diploma $1^{\text {st }}$ part- 3 Points

b. Banking diploma $2^{\text {nd }}$ part- 2 Points

a. For first 3 years- 12 points

b. For next every year- 1.50 points

c. For 9 months- 1.12 points

d. For 6 months- 0.75 points

e. For 3 months- 0.37 points 


\begin{tabular}{|c|c|c|c|}
\hline 5 & Other qualification & 3 & $\begin{array}{l}\text { a. For Working in Sylhet, Ctg. Hill track area/Bhola- Total } 1 \\
\text { point for officer whose home district is other than these } \\
\text { areas. } \\
\text { b. For working as branch Manager, up to } 2 \text { marks considering } \\
0.5 \text { marks for every year. }\end{array}$ \\
\hline 6 & Freedom fighter & 2 & $\begin{array}{l}\text { For Son/Daughter or Grandson/Grand Daughter of freedom } \\
\text { fighter- } 2 \text { points }\end{array}$ \\
\hline 7 & $\begin{array}{l}\text { Points by } \\
\text { selection/management } \\
\text { committee }\end{array}$ & 10 & $\begin{array}{l}10 \text { points are up to the selection/management committee that } \\
\text { might be awarded considering the last } 3 \text { years performance } \\
\text { where the pass mark is } 5 \text {. }\end{array}$ \\
\hline & Total & 100 & \\
\hline
\end{tabular}

Source: HR Policy Manual of Sonali Bank Ltd, 2016.

Table-1 represents the evaluation criteria and points distribution for promotion to the post of Deputy General Manager, Assistant General Manager, Senior Principal Officer, Principal Officer, Senior Officer and equivalent positions in Sonali bank ltd. Here, the qualifying marks for Deputy General Manager (DGM) is 90. The candidates with marks over 80 will be considered for promotion on seniority basis and the rest will be selected on merit basis. However, the qualifying marks for Assistant General Manager (AGM) is 90. The candidates with marks over 77 will be considered for promotion on a seniority basis and the rest will be selected on a merit basis. In the above case, the grading scale for 50 points of ACR consists of very good- 2.50 , good- 2.00, average1.00 and below-average- 0.00 .

\section{Rupali Bank Ltd.}

In Rupali Bank Ltd, the branch manager is responsible for rating the ACR of all the employees of that branch, and the branch manager, in turn, is evaluated by the zonal head. By maintaining the chain, the zonal head is evaluated by the divisional manager. The appraisal is done at the end of every year (Participant C). In Rupali bank, there is a structured appraisal form to conduct the ratings with established evaluation criteria for different positions designed by the HR division of the bank (Participant D). According to Participant C,

"The manager is independent in appraising the subordinates under his supervision. Thus, the managers' judgment
and observation about any employee matters most in case of performance ratings".

In this regard, participant $\mathrm{D}$ quoted that,

"The zonal head checks the ratings given by the branch manager and, if necessary, discuss with the manager about any discrepancy noticed but cannot force for change or modifications."

The ACR is kept confidential and, following the chain, submitted to the HR division of the bank. The HR division finally evaluates the appropriateness of the ratings and calculates the ultimate score for each employee. The ACR is kept in each employees' file and used as the fundamental instrument in case of promotion. Apart from the ACR, the branch manager also sets targets (deposit collection, loan recovery, accounts opening, etc.) for employees to be achieved at a designated period. Similarly, the branch manager is also given targets by the regional head, and the overall performance of a branch is considered as the achievement of the manager. The fulfillment of these targets influence the managers' ACR ratings and kept in his record for further career advancement (Participant C and D). 
Table-2: General Criteria of Performance Evaluation and Marks Distribution for Promotion in Rupali Bank Ltd.

\begin{tabular}{|c|c|c|c|}
\hline S.N. & Basis & $\begin{array}{l}\text { Total } \\
\text { Points }\end{array}$ & Segregation of Points \\
\hline 1 & ACR & 45 & The average point of the last 5 years ACR \\
\hline 2 & $\begin{array}{l}\text { Educational } \\
\text { qualification }\end{array}$ & 15 & $\begin{array}{l}\text { Educational qualification: } \\
\text { a. Masters } / 4 \text { years Honours- } 15 \text { Points } \\
\text { b. } 3 \text { years Honours } \backslash 4 \text { years diploma- } 13 \text { points } \\
\text { c. HSC } \backslash 3 \text { years diploma- } 11 \text { points } \\
\text { d. SSC or equivalent- } 10 \text { points }\end{array}$ \\
\hline 3 & Banking Diploma & 5 & $\begin{array}{l}\text { a. Banking diploma } 1^{\text {st }} \text { part- } 2 \text { Points } \\
\text { b. Banking diploma } 2^{\text {nd }} \text { part- } 3 \text { points }\end{array}$ \\
\hline 4 & $\begin{array}{l}\text { Length of Service } \\
\text { (In present grade) }\end{array}$ & 15 & $\begin{array}{l}\text { a. Per year } 1 \text { point (up to } 5 \text { points) } \\
\text { b. For every year (working as manager)- } 1 \text { point and for the rest period } \\
\text { 0.75, total } 10 \text { points. For other positions (who never worked as } \\
\text { manager), } 0.75 \text { per year up to } 10 \text { points. }\end{array}$ \\
\hline 5 & $\begin{array}{l}\text { Interview (Points } \\
\text { by management } \\
\text { committee) }\end{array}$ & 20 & $\begin{array}{l}\text { Up to } 20 \text { points awarded based on performance, knowledge and skills, } \\
\text { work experience, knowledge about current economic trends, presentation } \\
\text { skill, appearance etc. }\end{array}$ \\
\hline & Total & 100 & \\
\hline
\end{tabular}

Source: HR Policy Manual of Rupali Bank Ltd, 2011.

Table-2 shows the performance evaluation criteria with segregation of points for promotion from the post of Assistant General Manager to Deputy General Manager and Senior Principal Officer to Assistant General Manager in Rupali bank ltd. In this case, the grading scale for 45 points of ACR consists of very good- 0.39, good- 0.30 , average- 0.20 , poor- 0.10 and very poor- 0.00 .

Table-3: General Criteria of Performance Evaluation and Marks Distribution for Promotion in Rupali Bank Ltd.

\begin{tabular}{|c|c|c|c|}
\hline S.N. & Basis & $\begin{array}{l}\text { Total } \\
\text { Points }\end{array}$ & Segregation of Points \\
\hline 1 & ACR & 55 & The average point of the last 5 years ACR \\
\hline 2 & $\begin{array}{l}\text { Educational } \\
\text { qualification }\end{array}$ & 15 & $\begin{array}{l}\text { Educational qualification: } \\
\text { a. Masters / } 4 \text { years Honours- } 15 \text { Points } \\
\text { b. } 3 \text { years Honours } \backslash 4 \text { years diploma- } 14 \text { points } \\
\text { c. HSC } \backslash 3 \text { years diploma- } 12 \text { points } \\
\text { d. SSC or equivalent- } 11 \text { points }\end{array}$ \\
\hline 3 & Banking Diploma & 5 & $\begin{array}{l}\text { a. Banking diploma } 1^{\text {st }} \text { part- } 2 \text { Points } \\
\text { b. Banking diploma } 2^{\text {nd }} \text { part- } 3 \text { points }\end{array}$ \\
\hline 4 & Length of Service & 15 & $\begin{array}{l}\text { a. Per year } 2 \text { points (up to } 10 \text { points) } \\
\text { b. For every year (working as manager) } 1 \text { point and for the rest period } \\
0.75 \text {, total } 5 \text { points. For other positions (who never worked as } \\
\text { manager), } 0.75 \text { per year up to } 5 \text { points. }\end{array}$ \\
\hline 5 & $\begin{array}{l}\text { Interview (Points by } \\
\text { management } \\
\text { committee) }\end{array}$ & 10 & $\begin{array}{l}\text { Up to } 10 \text { points awarded based on performance, knowledge and skills, } \\
\text { work experience, knowledge about current economic trends, } \\
\text { presentation skill, appearance, etc. }\end{array}$ \\
\hline & Total & 100 & \\
\hline
\end{tabular}

Source: HR Policy Manual of Rupali Bank Ltd, 2011.

Table-3 represents the criteria wise points distribution for promotion from the post of Officer to Senior Officer, Senior Officer to Principal Officer and Principal Officer to Senior Principal Officer in Rupali bank ltd. Here, 
the grading scale for 55 points of ACR consists of very good- 0.478 , good- 0.350 , average- 0.250 , poor- 0.150 and very poor- 0.000 .

Table-4: General Criteria of Performance Evaluation and Marks Distribution for Promotion in Rupali Bank Ltd.

\begin{tabular}{llcl}
\hline S.N. & Basis & Total Points & \multicolumn{1}{c}{ Segregation of Points } \\
\hline $\mathbf{1}$ & ACR & 48 & $\begin{array}{l}\text { The average point of the last 5 years ACR } \\
\text { Educational qualification: } \\
\text { Masters or equivalent- 15 Points }\end{array}$ \\
& Educational qualification & 15 & $\begin{array}{l}\text { Honours- 13 points } \\
\text { HSC- 11 points }\end{array}$ \\
& & & $\begin{array}{l}\text { SSC- 10 points } \\
\text { Banking diploma 1st part- 2 Points } \\
\text { Banking diploma 2nd part- 3 points }\end{array}$ \\
$\mathbf{3}$ & Banking Diploma & 5 & $\begin{array}{l}\text { 2 points per year } \\
\text { Up to 12 points awarded based on satisfactory service and } \\
\text { performances (deposit collection, loan recovery, etc.) }\end{array}$ \\
$\mathbf{4}$ & Length of Service & &
\end{tabular}

Source: HR Policy Manual of Rupali Bank Ltd, 2011.

Table-4 indicates the performance evaluation criteria with marks distribution for promotion from the post of Junior Officer to Officer, Assistant Officer (grade-1) to Junior Officer, Assistant Officer (grade-2) to Assistant Officer (grade-1) and Office Assistant to Assistant Officer (grade-2) in Rupali bank ltd. Here, the grading scale for 48 points of ACR consists of very good- 1.00 , good- 0.75 , average- 0.50 , poor- 0.25 and very poor- 0.00 .

\section{Agrani Bank Ltd.}

Agrani Bank Ltd has converted its traditional ACR to the PER (Performance Evaluation Report) method for evaluating employee performance. According to Participant E,

"Our bank used ACR as a measuring tool for employee performances over the years, but recently the bank converted ACR into PER, which is an automatic scoring system."

The appraisal process is maintained over 12 months or one banking year. To set a standard to measure the level of performance, some achievement targets are set at the beginning of every year, and every employee is given a specific achievement target based on seven indicators as deposit collection, loan and advance, profit, noninterest income, export, import, and classified loan recovery. These seven performance indicators are also reflected in the quantitative part of the performance evaluation report (Participant F).

Participant F further added that,

\section{"Among the seven indicators, the three most common indicators for evaluating any general officer or executive are collecting a deposit, dispersing loans, and recovering classified loan from defaulters. Other indicators are used to evaluate the performances of specific desk related officers and the manager of the branch".}

According to Participant E, the performance evaluation report (PER) of Agrani bank ltd is consists of three parts. The first part comprises the basic information like the name, father's and mother's name, address, contact details, etc. The $2^{\text {nd }}$ and $3^{\text {rd }}$ part of the PER is used as the measuring tool for the employees' qualitative and quantitative performances. Since 2018, these part of PER has become automated and dedicated software has been used for this purpose. 
Participant E also stated that,

\begin{abstract}
"There is a point-based system for appraising employees. For example, employees with banking diplomas get additional points, and the M.B.A degree holders get more marks than the Graduate holders. The Office Head evaluates an employee's quality on a scale of 1 to 5 by assessing their work ethics, personality, leadership, behavior, etc. Here the boss also provides his opinion about the capability of the employee".
\end{abstract}

The appraisal form of Agrani bank is found on the bank's website. After filling it up, the form is digitally signed by the office head and his superior officer and submitted directly to the head office. The HRD receives this form from all over the country and makes it ready for the final evaluation by the top management. Usually, an evaluation team makes a list of employees based on the performance evaluation score and sends it to the board for final approval. Other than this structured criteria, the management committee also considers employees' achievements on pilot projects declared by the $\mathrm{MD}$ or $\mathrm{CEO}$ of the Bank to measure their performances (Participant E and F).

Table-5: General Criteria of Performance Evaluation and Marks Distribution for Promotion in Agrani Bank Ltd.

\begin{tabular}{|c|c|c|c|}
\hline S.N. & Basis & $\begin{array}{l}\text { Total } \\
\text { Points }\end{array}$ & Segregation of Points \\
\hline 1 & ACR/PER report & 50 & $\begin{array}{l}\text { For GM promotion: The average point of the last } 3 \text { years } \\
\text { ACR is considered. } \\
\text { PER 2nd part (Qualitative Part)- } 50 \text { marks and 3rd part } \\
\text { ( } 50 \text { marks) is divided as Personal Traits- } 28 \text { marks and } \\
\text { Achieved Target- } 22 \text { marks. } \\
\text { (Total } 100 \text { points which is converted into } 50 \text { points). } \\
\text { For DGM Promotion: The average point of last } 5 \text { years } \\
\text { ACR is considered. } \\
\text { PER 2nd part (Qualitative Part)- } 50 \text { marks and 3rd part } \\
\text { (Achieved Target)- } 50 \text { marks. }\end{array}$ \\
\hline 2 & $\begin{array}{l}\text { Educational qualification/ } \\
\text { Merit evaluation }\end{array}$ & 8 & $\begin{array}{l}\text { Educational qualification: } \\
\text { Masters } / 4 \text { years Honours- } 5 \text { points } \\
3 \text { years Honours- } 3 \text { points } \\
2 \text { years Honours- } 3 \text { points } \\
\text { Merit evaluation: } \\
1 \text { st class- } 0.75 \text { points } \\
\text { 2nd class- } 0.50 \text { points } \\
\text { 3rd class- } 0.25 \text { points } \\
\text { (Candidates will not be considered for promotion if they } \\
\text { do not have an Honours degree). }\end{array}$ \\
\hline 3 & $\begin{array}{l}\text { Professional qualification } \\
\text { (Banking } \\
\text { Diploma/CA/ICMA) }\end{array}$ & 6 & $\begin{array}{l}\text { Chartered Accountant/Cost accountant/ Banking } \\
\text { Diploma (1st }+ \text { 2nd part)- } 6 \text { Points } \\
\text { CA/ICMA 3rd part/Banking diploma 1st part- } 3 \text { points }\end{array}$ \\
\hline 4 & $\begin{array}{l}\text { Length of Service (In } \\
\text { present grade) }\end{array}$ & 10 & $\begin{array}{l}\text { For every year } 2 \text { points and up to first } 4 \text { years- } 8 \text { points } \\
\text { For next every year- } 1 \text { point } \\
\text { For } 9 \text { months- } 0.75 \text { points } \\
\text { For } 6 \text { months- } 0.50 \text { points } \\
\text { For } 3 \text { months- } 0.25 \text { points }\end{array}$ \\
\hline 5 & $\begin{array}{l}\text { Branch Manager/Zonal } \\
\text { Head }\end{array}$ & 2 & $\begin{array}{l}\text { For } 3 \text { years- } 2 \text { points } \\
\text { For } 2 \text { years- } 1 \text { point } \\
\text { For } 1 \text { year- } 0.5 \text { points }\end{array}$ \\
\hline 6 & Freedom fighter & 2 & 2 points \\
\hline 7 & Computer Literacy & 5 & Awarded based on computer test. \\
\hline
\end{tabular}




\begin{tabular}{llcl}
\hline $\mathbf{8} \quad$ Viva voce & 12 & $\begin{array}{l}\text { Professional knowledge- } 3 \text { points } \\
\text { Leadership and management- } 3 \text { points } \\
\text { Personality and trait- } 2 \text { points } \\
\text { Language knowledge- } 2 \text { points } \\
\text { Overall aptitude- } 2 \text { points } \\
\text { A Presentation }\end{array}$ \\
Total & 5 & $\begin{array}{l}\text { A PowerPoint presentation on a selected topic and an } \\
\text { assignment have to be submitted. }\end{array}$ \\
\hline
\end{tabular}

Source: HR Policy Manual of Agrani Bank Ltd, 2018.

Table-5 represents the points distribution of different criteria for promotion from the post of Assistant General Manager to Deputy General Manager and Deputy General Manager to General Manager in Agrani bank ltd. For these posts, there are no cut-off marks. Still, every candidate has to achieve at least $60 \%$ of the marks of viva voce, computer test, and assignment $(12+5+5=22)$ to get the promotion. It is also to be noted that achieving a very high mark does not guarantee promotion to the next level for these positions as the ministry of finance will review the candidates and the promotion will be awarded based on the required number of positions for a specific year.

Table-6: General Criteria of Performance Evaluation and Marks Distribution for Promotion in Agrani Bank Ltd.

\begin{tabular}{|c|c|c|c|}
\hline S.N. & Basis & $\begin{array}{l}\text { Total } \\
\text { Points }\end{array}$ & Segregation of Points \\
\hline 1 & ACR/PER report & 55 & $\begin{array}{l}\text { PER } 2^{\text {nd }} \text { part (Qualitative Part)-50 marks and } 3^{\text {rd }} \text { part (Quantitative } \\
\text { Part)- } 50 \text { marks. } \\
\text { The average point of last } 5 \text { years ACR is converted into } 55 \text { points. }\end{array}$ \\
\hline 2 & $\begin{array}{l}\text { Educational } \\
\text { qualification/ } \\
\text { evaluation }\end{array}$ & 8 & $\begin{array}{l}\text { Educational qualification: } \\
\text { a. Masters } / 4 \text { years Honours- } 5 \text { points } \\
\text { b. } 3 \text { years Honours- } 3 \text { points } \\
\text { c. } 2 \text { years Honours- } 3 \text { points } \\
\text { Merit evaluation: } \\
\text { a. } \quad 1^{\text {st }} \text { class- } 0.75 \text { points } \\
\text { b. } \quad 2^{\text {nd }} \text { class- } 0.50 \text { points } \\
\text { c. } 3^{\text {rd }} \text { class- } 0.25 \text { points } \\
\text { (Candidates will not be considered for promotion if they do not have an } \\
\text { Honours degree). }\end{array}$ \\
\hline 3 & $\begin{array}{l}\text { Professional } \\
\text { qualification(Banking } \\
\text { Diploma/CA/ICMA) }\end{array}$ & 6 & $\begin{array}{l}\text { a. Chartered Accountant/Cost accountant/ Banking Diploma } \\
\left(1^{\text {st }}+2^{\text {nd }} \text { part }\right)-6 \text { points } \\
\text { b. CA/ICMA } 3^{\text {rd }} \text { part } / \text { Banking diploma } 1^{\text {st }} \text { part }-3 \text { points }\end{array}$ \\
\hline 4 & $\begin{array}{l}\text { Length of Service (In } \\
\text { present grade) }\end{array}$ & 10 & $\begin{array}{l}\text { a. For every year } 2 \text { points and up to first } 3 \text { years- } 6 \text { points } \\
\text { b. For next every year- } 0.8 \text { points } \\
\text { c. For } 9 \text { months- } 0.60 \text { points } \\
\text { d. For } 6 \text { months- } 0.40 \text { points } \\
\text { e. For } 3 \text { months- } 0.20 \text { points }\end{array}$ \\
\hline 5 & Other qualification & 4 & $\begin{array}{l}\text { a. For working in Head office/ Controlling office/ Rural Branch } \\
\text { Manager/ City Branch Manager- Total } 3 \text { points based on tenure } \\
\text { and working place } \\
\text { b. Ctg. Hill track area/Bhola- Total } 1 \text { point for officers whose } \\
\text { home district is other than these areas. }\end{array}$ \\
\hline 6 & Freedom fighter & 2 & $\begin{array}{l}\text { For Son/Daughter or Grand Son/Grand Daughter of freedom fighter- } \\
2 \text { points }\end{array}$ \\
\hline 7 & Computer Literacy & 5 & Awarded based on computer test. \\
\hline
\end{tabular}


Viva voce

Total

100
a. Professional knowledge- 3 points
b. Leadership and management- 3 points
c. Personality and trait- 2 points
d. Language knowledge- 2 points
e. Overall aptitude- 2 points

Source: HR Policy Manual of Agrani Bank Ltd, 2018.

Table-6 shows the performance evaluation criteria with segregation of points for promotion from the post of Senior Principal Officer to Assistant General Manager in Agrani bank ltd. Similar to DGM to GM and AGM to DGM promotions, the AGM candidates also have to achieve at least $60 \%$ of viva voce, computer test, and assignment marks. And the 10 marks of viva-voce will be provided individually by every member of the board, and an average of those marks will be awarded to the candidate.

Table-7: General Criteria of Performance Evaluation and Marks Distribution for Promotion in Agrani Bank Ltd.

\begin{tabular}{|c|c|c|c|}
\hline S.N. & Basis & Total Points & Segregation of Points \\
\hline 1 & ACR/PER report & 55 & $\begin{array}{l}\text { PER 2nd part (Qualitative Part)- } 50 \text { marks } \\
\text { (Quantitative Part)- } 50 \text { marks } \\
\text { The average point of last } 3 \text { years ACR will } \\
\text { into } 55 \text { points. }\end{array}$ \\
\hline 2 & $\begin{array}{l}\text { Educational qualification/ } \\
\text { Merit evaluation }\end{array}$ & 15 & $\begin{array}{l}\text { Educational qualification: } \\
\text { a) Masters } / 4 \text { years Honours- } 13 \text { points } \\
\text { b) } 3 \text { years Honours- } 12 \text { points } \\
\text { c) } 2 \text { years Honours- } 11 \text { points }\end{array}$ \\
\hline
\end{tabular}

Merit evaluation:

a) 1 st class- 0.50 points

b) $2^{\text {nd }}$ class- 0.40 points

c) $3^{\text {rd }}$ class- 0.25 points

3 Professional

6 qualification(Banking

Diploma/CA/ICMA)

$4 \quad$ Length of Service (In present grade)

$5 \quad$ Other qualification

$6 \quad$ Freedom fighter

$7 \quad$ Points by management committee
6 a. Chartered Accountant/Cost accountant/ Banking Diploma ( $1^{\text {st }}+2^{\text {nd }}$ part $)-6$ points

b. CA/ICMA $3^{\text {rd }}$ part/ Banking diploma $1^{\text {st }}$ part- 3 points

a. For every year 2.5 points and up to first 3 years7.5 points

b. For next every year- 1.25 points

c. For 9 months- 0.90 points

d. For 6 months- 0.60 points

a. For working in Head office/ Controlling office/ Rural Branch Manager/ City Branch ManagerTotal 5 points based on tenure and working place

b. Ctg. Hill track area/Bhola- Total 1 point for officer whose home district is other than these areas.

For Son/Daughter or Grand Son/Grand Daughter of freedom fighter- 2 points

1 point is up to management committee that might be awarded considering last 3 years performance.

Total

Source: HR Policy Manual of Agrani Bank Ltd, 2018. 
Table-7 indicates the criteria wise allocated marks for promotion from the post Officer/Officer (cash) to Senior Officer, Senior Officer to Principal Officer and Principal Officer to Senior Principal Officer in Agrani bank ltd. For these positions, achieving marks above $90 \%$ is considered excellent, $80 \%$ to $89 \%$ is considered good, $70 \%$ to $79 \%$ is considered moderate, and below $70 \%$ is considered below average. For officers up to SPO, $75 \%$ of the promotion is awarded on a merit basis and the rest $25 \%$ is awarded on a seniority basis.

However, Agrani bank ltd still uses the traditional ACR for evaluation and promotion from the position of MLSS staff to Officer/Officer (cash), Attorney Assistant, and UDA. There is no PER for this level of employees. The 100 marks are divided into several parts, like other positions. In this case, the ACR holds 60 points (12 columns ACR whereas 5 points awarded for achieving excellent, 4 points for good, and 2 points for moderate). The educational qualification and merit evaluation cover 14 points (Masters/4 years Honours-14 points, 3 years Honours- 13 points, Honours: pass course- 12 points, HSC- 11 points and SSC- 10 points where additional points for merit are allotted as, 1 st class- 0.50 points, 2 nd class- 0.40 points and 3 rd class- 0.25 Points). The professional qualification covers a total of 6 points where for Chartered Accountant/Cost Accountant/Banking diploma (1st +2 nd part)- 6 Points and CA/ICMA 3rd part/ Banking diploma 1st part 3 points. Here, the length of service (in present grade) holds up to 17 points (For every year- 3 points and up to first 3 years- 9 points, for next every year- 0.8 points, for 9 months- 0.60 points, for 6 months- 0.40 points and for 3 months- 0.20 points). Along with this, 2 points are allotted for the son/daughter or grandson/granddaughter of freedom fighter and 1 point for working in remote areas and hill tracks for employees whose home district is other than these areas. Moreover, for promotion to officer/officer (cash) from MLSS posts, $50 \%$ of the promotion is awarded on a merit basis and the rest $50 \%$ is awarded on a seniority basis (Source: HR Policy Manual of Agrani Bank Ltd, 2018).

\section{Feedback of the Performance Appraisal System}

The performance appraisal tools are usually used to enhance banks' performance by putting the right person at the right place, which is done through transfers and promotions. Whereas transfer is usually regarded as punishment, promotion is viewed as a reward (Moyal \& Iyengar, 2016). In public commercial banks of Bangladesh, the reward of the employee for a good performance is provided through promotion, foreign training and congratulatory letter or transfer to a place where the employee wants to get posted (Participant F). Participant C from Rupali bank quoted that,

\section{"The results of performance appraisal are provided in written form and preserved in the employee's personnel file which been reviewed during the time of his or her promotion."}

Participant E from Agrani bank mentioned that, for giving promotions, a cut off mark or qualifying mark is determined every year by the bank's management committee to consider that years' promotion based on the number of posts filled through promotions. Participant E also stated that,

\section{"The employee is not considered for a next promotion until he spends at least 3 years in his or her present position no matter how good his performance is for the considering year".}

The rewards for managerial positions are slightly different than other positions. Along with ACR ratings, the managers could also get rewarded for outstanding performance of their respective branch and for fulfilling the targets given by their superiors (Participant D). By supporting the statement, Participant C from Rupali bank said that, 


\section{"If the target gets fulfilled, the manager awarded with increment as well as other financial rewards by the bank. They also recognized with awards like, 'Manager of the Year' and these success added in their file for further career advancement".}

While discussing the feedback of poor performances, Participant B from Sonali bank stated that,

\section{"If any employee achieves poor ACR points, then he might get a transfer from his present workplace to a remote area as a punishment transfer or by asking an explanation call and notifying about poor performance."}

The supportive statement was also given by Participant $C$ from Rupali bank as,

$$
\begin{gathered}
\text { "While reviewing the personal file, the poor ACR ratings puts a negative effect in evaluating the employees' eligibility } \\
\text { for next promotion." }
\end{gathered}
$$

In the case of Sonali and Agrani bank, any employee serving or served a punishment will not be considered for promotion unless he or she spends at least 2 years after punishment is over (Participant A and E). Whereas in the case of Rupali bank, the duration is 3 years, and the punished employees' increment remains postponed for up to 2 years (Participant D). Besides promotion, every active employee (who is not in any punishment) gets a yearly increment every year within his or her salary scale which is also influenced by the results of the employees' performance appraisal (Participant A and C).

\section{Discussion}

The study tried to show the present scenario of performance appraisal and promotion practices of the Sonali Bank Ltd, Rupali Bank Ltd and Agrani Bank Ltd in Bangladesh. All the three banks use the Annual Confidential Report (ACR) method to evaluate employee performances, whereas Agrani bank ltd has recently converted its ACR into PER (Performance Evaluation Report). As PER is an automated system with dedicated software, so it can be said that, Agrani bank is in a position of one step ahead than others on performance ratings. On the other hand, Sonali and Rupali banks are still far behind digitizing the performance evaluation system.

In case of promotion policy, the study found that, all the three banks have established criteria with allocated points for promotion to different positions. The common criteria include ACR, educational and professional qualification, length of service, interview, points by the management committee etc. In Sonali bank, the criteria and points for promotion to DGM, AGM, SPO, PO, SO, and equivalent positions are almost the same. The only difference is, for DGM and AGM, there are qualifying marks out of the total marks. In Rupali bank, the criteria for promotion to almost all the positions are the same but the marks distribution is slightly different. For example, the marks distribution for the ACR and management committee for promotion from the post of AGM to DGM and SPO to AGM is different than the promotion from Officer to SO, SO to PO, PO to SPO. Additionally, along with ACR and management committee, the points allocated for the length of service are also different for promotion from JO to Officer, AO (grade-1) to JO, AO (grade-2) to AO (grade-1), and OA to AO (grade-2) in Rupali bank ltd. However, Agrani bank ltd uses some additional criteria for performance evaluation than Sonali and Rupali bank such as points by the branch manager, computer literacy, viva-voce and presentation for promotion from AGM to DGM, DGM to GM, and SPO to AGM. The marks distribution for both cases are different and the candidates also have to achieve $60 \%$ marks in the viva, computer test, and assignment for being qualified for the promotion. In case of promotion from Officer to SO, SO to PO, and PO to SPO, there is a fixed percentage for merit (75\%) and seniority basis $(25 \%)$ and the points distribution for different criteria for these positions are also different than the previously mentioned positions. Moreover, the grading scales used for promotion to different positions for all the studied banks are also different. 
The study also found that the public banks of Bangladesh are heavily relying on the ACR method to conduct the employee appraisal with many limitations such as dependency on the manager, biasness of the rater, influence by external factors and lack of proper feedback to the employees. However, many banks are trying to shift their focus to other methods and the most common method apart from the ACR has been found as a target or goal-oriented system. The evaluation criteria and marks distribution may differ from bank to bank but the ultimate goal is to raise the employees' performance. The study thus creates an implication for the public banks to be more concerned about their performance appraisal method to keep the bank updated and be in a strong position in the intense market competition.

\section{Conclusion}

Performance appraisal is one of the most important facets of human resource initiatives. In this era of competition, every organization needs to use proper performance appraisal tools to get an appropriate outcome from their employees. The study found that Bangladesh's public commercial banks have a defined performance appraisal system in practice. Though they differ slightly from bank to bank, the ultimate objective is same. As almost all the banks are using ACR for performance appraisal, the study suggests to improve the indicators and eliminate the limitations of the method because an ineffective appraisal system would be a severe threat and loss to the resources of an organization. In almost all the banks in Bangladesh, the appraisal system is treated as a very secretive one, and not many employees know about the system in detail. Performance feedback gives employees who aren't meeting expectations a baseline about where they need to develop and encourages them to perform well (Vijay \& Jayachitra, 2010). Thus, Management should let the employee know about the performance appraisal system in practice.

Additionally, there should be clear and well-defined performance appraisal tools and evaluation criteria for the promotion. The management of the banking sector of Bangladesh should also be more concerned about introducing and maintaining employee engagement in the appraisal process. This will trigger the employees to achieve the goal and become more productive. Moreover, the evaluation by only supervisor is not a fruitful way to get exact outcomes. To prevent biases in subjective ratings, the banking sector should also initiate other methods of evaluation too. The banking industry of the country also needs to establish a uniform system of performance appraisal because discrimination in the same industry might lead to dissatisfaction among the employees and could decrease their productivity. The performance appraisal system can be made more effective if management rightly fit practice to purpose when setting goals and selecting appraisal techniques to achieve them (Manjunath, 2015). Hence, this study might help the policymakers to structure a more uniform and appropriate performance appraisal system for the financial sector of any country.

\section{Limitation and Way to Future Research}

The current study is mainly based on the three public commercial banks of Bangladesh. Thus, future studies may focus on other public banks of the country. However, further studies could be done on private commercial banks as well. There is also scope for conducting comparative studies on performance appraisal and promotion practices of public and private commercial banks in Bangladesh. The current study also has limitations regarding the small sample size. So, the sample size should be increased in further studies to improve the validity and acceptability of the results. Moreover, to overcome the geographical limitation of the present study, future studies could cover other geographical areas or countries with similar contexts.

Funding: This research received no external funding.

Conflicts of Interest: The authors declare no conflict of interest. 


\section{References}

Absar, M., Hossain, M., \& Alam, M. (2007). Employee performance appraisal in the banking sector of Bangladesh: The appraisees' perspective. The Cost and Management, 35(5), 81-86.

Aggarwal, A., \& Thakur, G. S. M. (2013). Techniques of performance appraisal-a review. International Journal of Engineering and Advanced Technology (IJEAT), 2(3), 617-621.

Armstrong, M. (2009). Armstrong's handbook of performance management: An evidence-based guide to delivering high performance: Kogan Page Publishers.

Bhatia, K., \& Jain, P. (2012). A study of performance appraisal and organizational effectiveness in terms of individual and organizational basis. A comparative study of BSNL and AIRTEL. International Journal on Arts, Management and Humanities, 1(1), 63-72.

Chen, J., \& Eldridge, D. (2010). Are "standardized performance appraisal practices" really preferred? A case study in China. Chinese Management Studies.

Chowdhury, A. (2002). Politics, society and financial sector reform in Bangladesh. International Journal of Social Economics.

Dessler, G. (2006). A framework for buman resource management: Pearson Education India.

Dobbins, G. H., Cardy, R. L., \& Platz-Vieno, S. J. (1990). A contingency approach to appraisal satisfaction: An initial investigation of the joint effects of organizational variables and appraisal characteristics. Journal of Management, 16(3), 619-632.

Gardner, C. (2008). Employee evaluation: is it worth the effort? DVM, 18(5), 647-681.

Gichuhi, A. W., Abaja, P., \& Ochieng, I. (2013). Effect of performance appraisal on employee productivity: A case study of supermarkets in Nakuru Town, Kenya. Asian Journal of Business and Management Sciences, 2(11), 42-58.

Gomez-Mejia, L. R., Balkin, D. B., Cardy, R. L., \& Carson, K. P. (2007). Managing human resources: Pearson/Prentice Hall Upper Saddle River, NJ.

Grote, R. C. (2002). The performance appraisal question and answer book: A survival guide for managers: AMACOM/American Management Association.

Hossain, M., Abdullah, A. M., \& Farhana, S. (2012). Performance Appraisal \& Promotion Practices on Private Commercial Bank in Bangladesh: A Case Study from Pubali Bank Ltd. Asian Business Review, 1(1), 4955.

Jahan, D. (2016). Employee Performance Appraisal System: A Study on Square Pharmaceuticals Limited. Journal of Business Studies, XXXVII (1), 49, 61.

Khan, M. F. U. (2013). Role of performance appraisal system on employees motivation. IOSR Journal of business and management, 8(4), 66-83.

Khanna, M., \& Sharma, R. K. (2014). Employees performance appraisal and its techniques: a review. Asian Journal of Advanced Basic Sciences, 2(2), 51-58.

Kondrasuk, J. N. (2011). So what would an ideal performance appraisal look like? Journal of Applied Business and Economics, 12(1), 57-71.

Latham, G. P., Borgogni, L., \& Petitta, L. (2008). Goal setting and performance management in the public sector. International Public Management Journal, 11(4), 385-403.

Latif, M. (2015). Employee Perception of Performance Appraisal: A Study on Janata Bank Limited. Journal of Business, 36(2).

Lawler III, E. E., \& McDermott, M. (2003). Current performance management practices. The Journal of Total Rewards, 12(2), 49.

Manjunath, K. (2015). Importance Of Performance Appraisal and Its Evaluation Parameters of Employees in Insurance Companies. International Journal of Research in Commerce, IT \& Management, 5(10), 58-62. 
Moyal, S., \& Iyengar, V. (2016). Performance Appraisal in Banks: A Study. ELK Asia PAsific Journal of Human Resource Management and Organisational Behaviour, 3(1), 1-8.

Obisi, C. (2011). Employee performance appraisal and its implication for individual and organizational growth. Australian Journal of Business and Management Research, 1(9), 92.

Rahim, S. A. (2012). Performance appraisal systems in private banks of Bangladesh: a study on the Mercantile Bank Limited. The Business \& Management Review, 3(1), 27.

Rahim, S. A., \& Islam, S. M. S. (2019). Performance appraisal system of Mercantile bank limited: An evaluation. Journal of Business and Retail Management Research, 13(4).

Rahman, M., Abdul, M., Ali, N., Uddin, M., \& Rahman, M. (2017). Employees' Retention Strategy on Quality of Work Life (QWL) Dimensions of Private Commercial Banks in Bangladesh. Pertanika Journal of Social Sciences \& Humanities, 25(2).

Rahman, M. M., Ali, N. A., Mansor, Z. D., Jantan, A. H., Samuel, A. B., Alam, M. K., \& Hosen, S. (2018). Work-family conflict and job satisfaction: The moderating effects of gender. Academy of Strategic Management Journal, 17(5), 1-6.

Rahman, M. M., Uddin, M. J., \& Rahaman, S. (2019). Work-family, family-work conflict and subjective wellbeing of commercial bank employees in Bangladesh: The moderating effects of organisational supports. Advances in Management and Applied Economics, 9(6), 77-96.

Seniwoliba, J. A. (2014). Assessing the performance appraisal concept of the Local Government Service in Ghana.

Shaout, A., \& Yousif, M. K. (2014). Performance evaluation-Methods and techniques survey. International Journal of Computer and Information Technology, 3(5), 966-979.

Talukdar, M. B. U., \& Saha, S. (2007). A Comparative Study of Performance Appraisal Systems of Two Private Commercial Banks.

Talukder, M. F. H., Hossain, M. Y., \& Hossain, M. N. (2014). HRM practice in commercial banks: A case study of Bangladesh. IOSR Journal of business and management, 3(2), 29-36.

Tziner, A., \& Kopelman, R. E. (2002). Is there a preferred performance rating format? A non-psychometric perspective. Applied Psychology, 51(3), 479-503.

Vijay, D. L., \& Jayachitra, B. (2010). Effectiveness of Performance Management System. International Journal of Advanced Research in Management (IJARM), 1(1), 53-59.

Wangithi, W. E., \& Muceke, N. (2012). Effect of human resource management practices on psychological contract in organizations. International Journal of Business and Social Science, 3(19), 117-122. 